\title{
ANALYSIS OF PERTAMINA RETAIL E-COMMERCE BUSINESS DEVELOPMENT STRATEGIES WITH A CANVAS MODEL BUSINESS APPROACH
}

\author{
Prori Vitaliano L.*, Syarief Rizal, Hasbullah Rokhani \\ Researchers, Indonesia \\ *E-mail: prori.vitaliano@gmail.com
}

\begin{abstract}
The competition of oil and gas industry in Indonesia is very tight. To get survive from the competition; the company has to develop their technology. PT. Pertaminan Retail is a large oil and gas company in Indonesia. This study analyzed the design of e-commerce business development models from PT. Pertamina Retail called MyPertamina. The method of the study is descriptive analysis and using business model canvas (BMC), the Delphi method, SWOT (Strengths, weakness, opportunities, \& threats), and the Blue Ocean Strategy. The secondary data obtained from the literature study and the primary data was by interviewing six informants. The research period starts from November to December 2018. The results of mapping the initial business model that used BMC, showed several aspects such as: customer segments, value propositions, channels, revenue streams, key resources, key activities, key partners, and costs structure. Environmental analysis used the Delphi method and the result was key trend value was $25.48 \%$, industry strength was $25.19 \%$, market strengths was $24.78 \%$, and macroeconomic strengths was $24.55 \%$. MyPertamina's internal environment influenced by product aspects, infrastructure management, customer interface, and financial aspect. The results of the SWOT analysis of nine BMC unsurts showed that the highest strength was the key partnership and the lowest strength was customer relationship. Meanwhile, the biggest opportunity was value proposition and the lowest opportunity was cost structure. The highest threat was customer segment, and the lowest threat was key partners. The business development model in this research focused on customer segment, key partnership, and value proposition, unsurts developed using the blue ocean strategy method.
\end{abstract}

\section{KEY WORDS}

E-commerce, MyPertamina, oil company, gas company, business model.

Petroleum commonly called fossil fuels is the main raw material for combustion that is most used by the world community today. Increased demand for crude oil and also with the fear of its availability caused oil prices to reach record highs in history in the 2000s.

PT. Pertamina Retail continues to strive to achieve its long-term plan which aims to become a classy global retail company by providing value from the diversification of the Fuel and Non-Fuel Retail business through integrated products and services in 2017. In the future, PT. Pertamina Retail will optimize and continue to develop its assets and infrastructure in order to maintain competitive advantage to become a company that contributes more to the Parent Company and the State, and continues to hold on to its commitment as a company that upholds professionalism, accountability and is oriented to customer comfort and satisfaction as quoted. from the Corporate Profile of PT. Pertamina Retail (2018).

Downstream fuel oil business competition in Indonesia is crowded by several large companies, namely Pertamina, Shell, Total, Petronas and most recently Vivo. In fact, one by one foreign competitors fell out, one of which was Petronas's Petrolas Gas Station. With the increasing number of players downstream both in the distribution and sale of fuel (BBM), the condition will be more competitive. But those who benefit are consumers.

Companies are required to anticipate in the face of changes in a very diverse and uncertain environment. Anticipation of these changes consists of company plans or strategies that are needed and are considered capable of handling these environmental 
changes. MyPertamina can be expected to be one of the marketing strategies that covers all levels of Indonesian society, so that the assistance of PT. Pertamina Retail, and PT. Pertamina (Persero) can be used as an international-based Petroleum Company.

At present, the existence of $\mathrm{E}$-Commerce is used as an alternative marketing strategy that affects the economic improvement of a company. According to a survey published by APJII (Association of Indonesian Internet Service Providers) in 2017, the highest percentage of internet user penetration was 143.26 million people or $54.68 \%$ of the total population of Indonesia.

Seeing the rapid development of E-Commerce, PT. Pertamina Retail decided to utilize the character of the Indonesian people with enough IT Oriented to increase the Company's revenue. One marketing strategy that has been carried out by PT. Pertamina Retail is MyPertamina. MyPertamina application is a smartphone-based application and E-Money card that is made to loyal consumers of Pertamina as a form of consumer loyalty to Pertamina. MyPertamina has several features namely e-Money which can be used to purchase Pertamina Products.

But since MyPertamina was first launched in 2017, it only got 10000 downloads, still far from what was expected. Based on that, the writer intends to conduct research on why this can happen, using the Businees Model Canvas method which can describe the business model used and for the development of the latest business model using the Blue Ocean Strategy method which is expected to open a way out to improve the performance of the unit MyPertamina business. According to Stefan and Richard (2014) the Osterwelder and Pigneur business model concept is the most complex business concept model and clearly describes not only economically and business processes but also creates value. The research objectives are (1) Identifying the E-Commerce business model implemented by PT. Pertamina Retail; (2) Developing the E-Commerce business model of PT. Pertamina Retail in the future; (3) Provide recommendations on the strategy and E-Commerce program of PT. Pertamina Retail in facing competition.

\section{METHODS OF RESEARCH}

The research location was chosen purposively at PT. Pertamina Retail which is a subsidiary of PT. Pertamina (Persero). Data sources used are primary and secondary data. Primary data obtained through in-depth interviews with selected respondents in the company, namely management who is responsible for the key activities of the company that will be used in identifying nine elements of Business Model Canvas (BMC). Internal and external company information is used as a basis for making business improvement models.

Secondary data obtained through literature studies in data provider agencies. This information is used to support the company's strategic decisions going forward. The information used is: the number of competitors, the strength of competitors, market share, socio-economic conditions of the community market area of the company, other than that other sources deemed relevant such as scientific journals and books are also used.

The data processing and analysis stage is done by mapping the current business model using Business Model Canvas (BMC), analyzing the internal and external environment with the Delphi method, evaluating the nine elements of BMC with the SWOT method, and making a business model design with the Blue Ocean Strategy (BOS).

\section{RESULTS AND DISCUSSION}

PT. Pertamina Retail (hereinafter referred to as the Company) is a subsidiary of PT. Pertamina Retail which is engaged in the retail business of Pertamina products. The company was founded on June 17, 1997, and originally named PT Pertajaya Lubrindo engaged in the business of Lubricants. On September 1, 2005, the Company changed its name to PT. Pertamina Retail. This change aims to deal with changes in the retail market, especially gas stations (General Fuel Filling Stations) in Indonesia towards the world free market 
PT. Pertamina Retail makes an innovation based on technological developments that can change money, business, and the world. This replacement is a continuation of the industrial revolution in ancient times where many factory workers were replaced with machinery / automation. PT. Pertamina Retail made an innovation, namely MyPertamina. MyPertamina is a combination of Pertamina's loyalty program and the use of electronic money or cashless payment. The use of electronic money is done by two methods, namely by card or smartphone application.

The identification of business model patterns is done by questionnaire interviews aimed at getting an overview and information about the nine elements of the Canvas Business Model block which is the easiest means to understand patterns with a company's business. Questionnaire interviews were conducted with management and implementers of MyPertamina such as customer segments, value propositions, customer relationships, channels, revenue streams, key partners, key activities, key resources, and cost structures. The MyPertamina business model can be mapped as shown in Figure 1.

\begin{tabular}{|c|c|c|c|c|}
\hline Key Partners & Key Activity & Value Propositions & $\begin{array}{c}\text { Customer } \\
\text { Relationship }\end{array}$ & $\begin{array}{c}\text { Customer } \\
\text { Segmentation }\end{array}$ \\
\hline $\begin{array}{c}\text { Agency IT } \\
\text { Bank BUMN } \\
\text { Bank Indonesia } \\
\text { Merchandiser } \\
\text { Store }\end{array}$ & $\begin{array}{c}\text { Branding/Promotion } \\
\text { Developing } \\
\text { Application } \\
\text { Maintenance Server } \\
\text { Account } \\
\text { Management } \\
\text { Research }\end{array}$ & $\begin{array}{l}\text { User Friendly } \\
\text { Application } \\
\text { Novelty } \\
\text { Cashless } \\
\text { Convenience }\end{array}$ & $\begin{array}{c}\text { Komunitas } \\
\text { Event Promotion } \\
\text { Loyalty Program } \\
\text { Dedicated Personal } \\
\text { Assistant }\end{array}$ & $\begin{array}{c}\text { Pertamax Turbo } \\
\text { Pertamina Dex } \\
\text { Consumer }\end{array}$ \\
\hline \multicolumn{2}{|c|}{ Key Resources } & \multicolumn{2}{|c|}{ Channels } & \\
\hline \multicolumn{2}{|c|}{$\begin{array}{c}\text { SDM/Intelektual } \\
\text { Teknologi } \\
\text { Brand/ HAKI } \\
\text { Finance }\end{array}$} & \multicolumn{2}{|c|}{$\begin{array}{c}\text { Media Sosial } \\
\text { Booth Event } \\
\text { Brand Ambassador }\end{array}$} & \\
\hline \multicolumn{2}{|c|}{ Cost Structure } & \multicolumn{3}{|c|}{ Revenue Stream } \\
\hline \multicolumn{2}{|c|}{$\begin{array}{c}\text { Maintenance IT Cost } \\
\text { Agency IT Cost } \\
\text { Salary } \\
\text { Promotion Cost } \\
\text { Production Cost }\end{array}$} & \multicolumn{3}{|c|}{ Fee Transaction } \\
\hline
\end{tabular}

Figure 1 - Mapping the MyPertamina business model with BMC

MyPertamina's business is focused on determining Customer Segments based on the types of products marketed. This segmentation division becomes Pertamax turbo. Consumers of Pertamax Turbo are the owners of the latest vehicles with advanced engine alloys that require high-quality fuel. Users expect several advantages from Pertamax Turbo. The next segmentation is Pertamina Dex, in addition to having a Cetane Number (CN) 53 and low sulfur, it can clean the engine, prevent rust, water contamination and foaming. "In short Pertamina Dex is very appropriate for diesel vehicles that want maximum and powerful performance. The next segment is the automotive community, basically automotive activists are also users of fuel, and this community is used as a customer segment for the development of marketing activities, because basically the automotive community is also the user of Pertamax Turbo or Pertamina Dex.

According to Kaplan \& Norton (2001), a value proposition is a value that is channeled, communicated, and known. Value propositions can be applied to all organizations, consumers, products or services. The MyPertamina application is considered to have user friendly characteristics because of the ease of use of its features and also its simple and minimalist appearance makes it easy for consumers to understand and run the application properly.

According to Drucker (1996), Innovation or novelty is done by creating new production resources and processing of existing resources, with the aim of adding potential value. This value addition is carried out with the latest technology to accommodate the wants and needs 
of Pertamina's consumers. MyPertamina is an innovation from PT. Pertamina Retail aims to attract new customers and retain old customers with the help of the latest technology.

According to Suki (2002), convenience can be determined as a driving factor for online purchasing decision making. Convenience related to time, space, and savings made by consumers, there is no queue or density and time. Seider et al (2000) provide four ways to provide convenience, namely: the convenience of access, search, possession, and transaction convenience.

Channels are an illustration of the way companies communicate and deliver value propositions, distribution, and sales to customers. Kotler \& Keller (2008), describes three types of marketing channels which include: communication channels, distribution channels, and service channels.

MyPertamina realizes that social media is a very appropriate platform to enhance its brand, with social media Facebook and Instagram. The number of automotive and community events makes MyPertamina enter booths at these events as a medium to deliver product value to prospective customers. MyPertamina uses a brand ambassador with the aim of building MyPertamina brand awareness and leading new customers to use MyPertamina products.

Customer Relationship shows the patterns and types of relationships built by MyPertamina with customers. MyPertamina realizes that relationships with the community are expected to be a place to filter information and input from MyPertamina users, and the community gets appropriate feedback such as community support events.

MyPertamina's effort in increasing its relationship index with consumers is through initiatives on several loyalty programs that are expected to increase the level of loyalty to consumers. The third MyPertamina business is the Dedicated Personal Assistant. MyPertamina realizes that applications that get the attention of many consumers must have very professional services and are dedicated to providing convenience to their customers.

The Revenue Stream element shows the revenue that the company receives in each customer segment. In the case of MyPertamina, MyPertamina gets income from Service Revenue. In reaching this type of income, MyPertamina applies transaction fees when consumers make transactions or top up using MyPertamina balance. This is MyPertamina's main strategy in increasing their service revenue, because MyPertamina believes that this type of revenue will always contribute continuously to MyPertamina's revenue.

Key Partners are defined as a relationship between a supplier or partner and a company, so that the business model can run. Companies have partner relationships for a variety of reasons, and this is the basis of various business models

IT Agency is a form of collaboration produced between MyPertamina and parties related to the production and maintenance of applications. Bank BUMN is a contractual form of this cooperation, because MyPertamina also sees the level of community attention to this form of cooperation through various promotional programs to increase public response. The Central Government is MyPertamina needs to increase special attention on the type of relationship, because MyPertamina is very dependent on the existence of the central government in determining the smoothness of this application. The current relationship with Bank Indonesia, MyPertamina uses the e-cash system as a form of compliance in the cashless society policy as the policy is an initiative of Bank Indonesia. MyPertamina certainly needs to re-evaluate again, to see whether the payment system is still relevant to the nature of the community. Merchandiser Store is a type of relationship that occurs is in channeling sales offline, especially for people who still have limited knowledge about sales channels for MyPertamina merchandise.

MyPertamina realizes the importance of Key activity as an important component of the application, resulting in the realization of: (a) Application Branding, MyPertamina needs an activity to increase brand recognition to the community, by utilizing brand ambassadors to carry out the branding, (b) Application Development, MyPertamina realize that the IT world is moving very fast and dynamically, so that application updates are needed, in order to reach all MyPertamina stakeholders, (c) Application Maintenance Server, To improve services for technical problems in applications, (d) Account Management, Protection of consumer data 
for avoid spying and information breaching from other companies / competitors, (e) Research, to find out the trends that consumers are interested in and the strategies needed to achieve these goals.

In the context of MyPertamina there are three Key Resources that are used, namely: a) Human Resources (HR), In accordance with the vision and mission of PT. Pertamina (Persero) that HR is the main asset that contributes to the development of the company, because HR greatly influences the direction of the Company's performance. b) Brand / Intellectual Property Rights, MyPertamina realizes that this application product is owned by a reputable company, so protection of the application is needed through brand development and Intellectual Property Rights (IPR), so that competitors cannot legally copy them as they like, and so MyPertamina has an identity unique. c) Financial, which is very important for MyPertamina's operational activities, through structured and detailed budgeting.

MyPertamina describes their focus cost structure into several aspects, such as: (a) Information Technology Maintenance Costs, (b) Information Technology Agencies, (c) HR Salaries, (d) Promotion Costs, (e) Production Costs.

Internal Environmental Analysis. Internal business environment analysis is carried out to provide a good overview and understanding of the business environment that can be controlled by the company. Understanding the internal environment is done by scanning the structure of the internal environment that is part of the MyPertamina business model. These results are taken into consideration to formulate a business model that is more accurate and competitive. Internal environmental aspects used for this study include product, customer interface, infrastructure management, and financial aspects according to Osterwelder and Pigneur (2015).

1. Product. Identification of the internal environment in MyPertamina get factors that affect the internal environment in aspects of the product, (features and services, security level), User Experience, User Interface, and Product Development. The company gives a very important assessment on the aspects of features and services, the level of security, user experience, and product development. Demanding the company's features, product development, safety, and consumer convenience in using products is the main thing to maintain the company's sustainability.

2. Customer Interface. Factors that can affect the Customer Interface with the first importance are Brand Activation, and Media Information. MyPertamina carries out brand activation activities at launching up to automotive events, by opening booths and introducing products to prospective customers directly to feel and be sure to become one of the new customers.

The next factor to be considered is the information media, the company needs to build relationships with consumers more closely with the information media we provide the latest information on target and efficiently.

3. Infrastructure Management. Infrastructure management is a factor that affects the company's operations. Things that are considered important in the company include HR skills, corporate culture, and technology. HR skills are one of the main factors in building a business, because good human resources produce optimal production activities, as well as technological factors, which are adequate, resulting in productivity at work.

4. Financial Aspect. Things that affect the financial aspects of MyPertamina include the ability of company capital, good relations with IT consultants, and financial management. As a subsidiary of a large company, Pertamina Retail also has an important task in developing the company in general, so this capital capability factor can be carefully calculated. Use more facilities and facilities that have been available, so take the decision to use the services of IT consultants who are considered competent. The cost of the IT consultant emphasizes better financial management.

External Environmental Analysis:

1. Key Trends. Key trend analysis gets the first biggest percentage ranking with a value of $25.48 \%$. This analysis is based on aspects that are considered to affect MyPertamina's business, namely community and cultural trends, regulatory and political trends, socioeconomic trends, and technology trends. In the external environment, MyPertamina's 
regulatory and political trends received the greatest importance assessment, because they were influenced by Pertamina's existence as an Indonesian SOE whose activities were highlighted by the central government. In general, the government through its regulations and politics can influence directly or indirectly to support or complicate MyPertamina's business activities.

2. Market Strength. Aspects of market power get the third largest percentage after industrial strength $(24.78 \%)$. The assessment uses aspects that are felt to affect the company's business. Aspects used include market issues, market segmentation, demand needs, moving costs, and the attractiveness of revenue.

Market issues get the highest level of importance among other aspects. Market issue that is in the spotlight is cashless society. In line with Bank Indonesia's regulations regarding electronic money, many companies have tried to implement an electronic money system based on cashless society. According to Dave (2016), there are several benefits of cashless money, namely: (1) Providing convenience and comfort in transactions; (2) Provides a smaller level of risk; (3) Provides control of economic regulation.

3. Industrial Strength. The industrial strength aspect gets the second largest percentage rating after the key trend, which is $25.19 \%$. The assessment uses aspects that affect MyPertamina's business, namely competition, new players, substitute products and services, suppliers, and stakeholders.

The aspect of competition gets the assessment of the highest level of importance among other aspects. Realizing the importance of competition in the downstream retail business of vehicle fuels, Pertamina Retail made an innovation that was expected to be sufficient and could make it stay as a market leader, namely MyPertamina. MyPertamina should bear a heavy burden as an innovation that follows technology trends, in addition to the substantial costs.

4. Macroeconomic Strength. Aspects of macroeconomic strength get the smallest percentage (24.55\%). This aspect of macroeconomic strength is assessed using aspects, namely global market conditions, and other commodities and resources. Aspects of global market conditions have the greatest importance. Indicators of a weaker exchange rate and world oil prices are aspects of global market conditions that affect the Pertamina Retail ECommerce business.

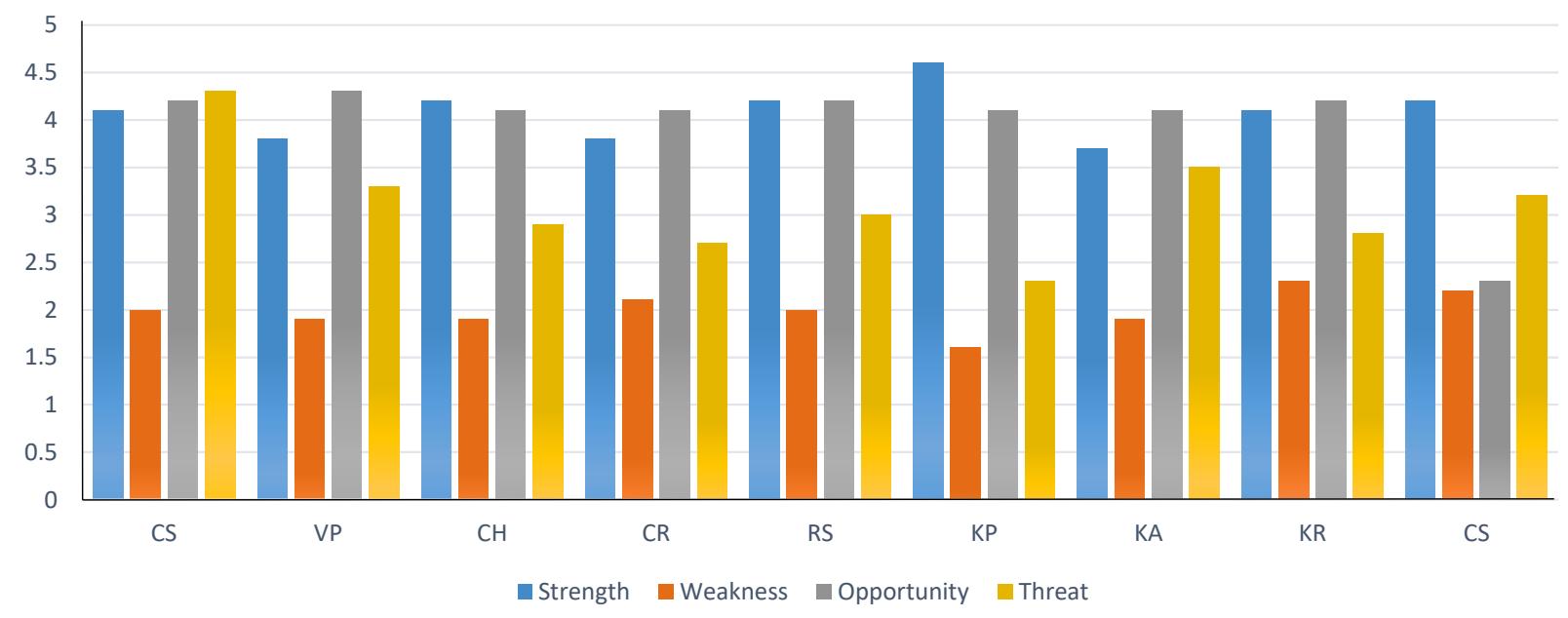

Figure 2 - SWOT graph on nine elements of BMC

\section{Business Model Evaluation:}

1. Customer Segments. The results of customer segment evaluations have very high strength (4.1), very low weakness (2), very high chance (4.2), and very high threat (4.3). Opportunities are very high because the Indonesian people already know the quality and value of the benefits of Pertamina products that carry the Indonesian Pride, so people are proud to use Indonesian special products. 
2. Value Propositions. The results of the value propositions evaluation show that these strengths have a high enough index (3.8), low weakness (2.1), very high chance (4.1), and threat $=$ low enough (2.7). The high opportunity index in the value proposition segment is caused by the existence of Pertamina which is considered to be "monopolizing" sales of petroleum products.

3. Customer Relationships. The results of the evaluation of customer relationships indicate that strengths are in the index quite strong (3.8), have very low weaknesses (2.1), very high odds (4.1), and threats are quite low (2.7). What needs to be underlined in the high opportunity index in this segment is Pertamina's factor that has been standing longer than other petroleum companies. This is also influenced by the important role of the Indonesian government in improving Pertamina's relationship with consumers through the BBM subsidy program which is expected to be "closer" to consumers with Pertamina.

4. Channels. The results of this segmentation evaluation have very high strengths (4.2), very low weaknesses (2), very high odds (4.2), and high enough threats. The high strength and opportunity index is largely influenced by the existence of Pertamina's subsidiary which is expected to support the company's efficiency, as well as increase the company's economic contribution.

5. Revenue Streams. The evaluation index of revenue stream segmentation has very high strength (4.2), very low weakness (2), very high chance (4.2), and high enough threat (3). The high strength and opportunity index is largely influenced by the high operational cost provided by PT. Pertamina Retail to MyPertamina, so that MyPertamina can decide on parties to cooperate with having high competence.

6 . Key Activities. The results of observations on this segmentation have a high enough strength index (3.7), very low weakness (1.9), very high odds (4.1), and high enough threats (3.5). The high opportunity index from segmentation is shown by the vast area of sales and marketing distribution as indicated by the monopolization of the petroleum market from PT. Pertamina (Persero).

7. Key Resources. The results of evaluating key resources have very high strengths (4.1), very low weaknesses (2.3), very high odds (4.2), and low threats (2.8). The high strength index is largely influenced by the number of adequate intellectual, human and financial aspects, so MyPertamina believes that its application can compete reliably in the domestic market.

8. Key Partners. Key partner evaluation results have very high strengths (4.6), very low weaknesses (1.6), very high opportunities (4.1), and low threats (2.3). The high strength index is caused by the high Buyer-Supplier Relationships index as indicated by the interaction between owner and vendor.

9. Cost Structure. The cost structure evaluation results have very high strengths (4.2), very low weaknesses (2.2), very low opportunities (2.3), and high enough threats (3.2). The very high strength index is influenced by the implementation of the product-cost, servicecost, product line cost, and customer cost strategies.

According to Giesen et al (2007) a focus on business model innovation is the best way to handle major changes in an industry to improve company competitiveness. Analysis of Development of the MyPertamina business model is briefly explained in Figure 3 . The results of the analysis of the development of the business model are then directed at the customer segmentation aspect. The change in Customer Segmentation from the MyPertamina business model will have a broad impact on the development of future business models. The initial change was very specific to be more general with many new customer criteria. For this reason, it was decided to focus more and intensely on government and private service vehicles which were expected to be useful in helping to eradicate fraud in operational environments related to vehicle fuel. MyPertamina needs to add prestige to its application, integrating by providing some merchandise that can be purchased exclusively and openly for consumers to transact through the point system. Point system accumulated transaction results from the purchase of BBM Pertamax series. In addition, this prestige aspect is also obtained from the privilege system for consumers who use MyPertamina "special lane" to purchase fuel at this particular gas station as a means of payment at Pertamina's gas station. 


\begin{tabular}{|c|c|c|c|c|}
\hline Key Partners & Key Activity & Value Propositions & $\begin{array}{c}\text { Customer } \\
\text { Relationship }\end{array}$ & $\begin{array}{c}\text { Customer } \\
\text { Segmentation }\end{array}$ \\
\hline $\begin{array}{c}\text { Agency IT } \\
\text { Bank BUMN } \\
\text { Bank Indonesia } \\
\text { Merchandiser } \\
\text { Store } \\
\text { Perusahaan } \\
\text { Swasta } \\
\text { Pemerintah } \\
\text { Pusat } \\
\end{array}$ & $\begin{array}{l}\text { Branding/Promotion } \\
\text { Developing } \\
\text { Application } \\
\text { Maintenance Server } \\
\text { Account } \\
\text { Management } \\
\text { Research }\end{array}$ & $\begin{array}{l}\text { User Friendly } \\
\text { Application } \\
\text { Novelty } \\
\text { Cashless } \\
\text { Convenience } \\
\text { Prestige }\end{array}$ & $\begin{array}{c}\text { Komunitas } \\
\text { Event Promotion } \\
\text { Loyalty Program } \\
\text { Dedicated Personal } \\
\text { Assistant }\end{array}$ & $\begin{array}{c}\text { Pertamax Turbo } \\
\text { Customer } \\
\text { Pertamina Dex } \\
\text { Customer } \\
\text { Automotive } \\
\text { Community } \\
\text { Government Service } \\
\text { Vehicles }\end{array}$ \\
\hline \multicolumn{2}{|c|}{ Key Resources } & \multicolumn{2}{|c|}{ Channels } & Private Service \\
\hline \multicolumn{2}{|c|}{$\begin{array}{l}\text { SDM/Intelektual } \\
\text { Teknologi } \\
\text { Brand/HAKI } \\
\text { Finansial } \\
\end{array}$} & \multicolumn{2}{|c|}{$\begin{array}{l}\text { Media Sosial } \\
\text { Booth Event } \\
\text { Brand Ambassador } \\
\text { Booth Activation } \\
\end{array}$} & $\begin{array}{c}\text { Vehicles } \\
\text { Online Transportation } \\
\text { Partner }\end{array}$ \\
\hline \multicolumn{2}{|c|}{ Cost Structure } & \multicolumn{3}{|c|}{ Revenue Stream } \\
\hline \multicolumn{2}{|c|}{$\begin{array}{l}\text { Maintenance IT Cost } \\
\text { Agency IT Cost } \\
\text { Salary } \\
\text { Promotion Cost }\end{array}$} & \multicolumn{3}{|c|}{$\begin{array}{c}\text { Fee Transaction } \\
\text { Afiliasi dengan pihak lain }\end{array}$} \\
\hline
\end{tabular}

Figure 3 - Analysis of the development of the MyPertamina business model

Another strategy that needs to be improved by the MyPertamina team is the approach to the community strategy. As with the customer segmentation aspect, MyPertamina needs to focus its attention on the motor vehicle community, because the community is considered to be able to provide better product loyalty and can contribute to a large income.

MyPertamina gives a bargaining offer to the vehicle community about MyPertamina being very focused and close in maintaining the engine, so that the community is loyal to the MyPertamina brand.

The existence of brand activation in developing the MyPertamina business, especially to some underdeveloped regions. Seeing this, things that can be done besides using the MyPertamina brand ambassador, with social charity or education charity that is expected to bring MyPertamina closer to the community.

There is an income other than transaction fees, affiliation with third parties, Indonesian unicorns in the field of transportation (Go-Jek). In this case MyPertamina will present as a financial solution, which must first disburse the funds applied to buy fuel. Pertamina Retail won't be as easy as using the Go-Pay application for payment because we have MyPertamina for cashless payment facilities, an effort that MyPertamina needs to do is to be able to change Go-Pay digital money into MyPertamina digital money so that Go-Jek partners can make transactions at gas stations cashless basis.

In order to anticipate the lack of performance of the company's business, MyPertamina should be "open" with other start-up companies, because these companies are considered to be able to reach wider consumers, thus providing enormous revenues.

Key activities in the MyPertamina business model are still minimal indicators, namely applications that need to get lesson learned, especially in research and development activities. related to the renewal of technological features or other types of services.

A very important element in improving the quality of Key resources in the MyPertamina business model is an increase in the budget for its application. If the management team is willing to increase the operational budget for developing the application, it will help other key resource activities, such as human resource development, technology development, and brand development or IPR.

Overall, there needs to be a balance between the four elements of the cost structure, anticipating the situation due to the imbalance of each of the four elements of the cost structure. For example, for the IT maintenance element, if the MyPertamina management team does not allocate funds to the aspects of IT maintenance, surely the IT Agency is not working optimally so that bugs that interfere with application performance will run poorly. 


\section{CONCLUSION}

The identification of the MyPertamina business model shows that the internal analysis of Product aspects including features and services has the greatest importance, which is $25.98 \%$. External analysis shows aspects of key trends such as regulatory and political trends with a level of importance of $24.48 \%$. The evaluation results from nine BMC elements with SWOT analysis showed the highest strength in the Key Partners element, the highest weakness in the Key resources element, the highest opportunity in the Value proposition, and the highest threat in the Customer segment.

The development of the MyPertamina e-commerce business model was developed through the Customer Segment element by eliminating initial segments by replacing government service vehicles, private service vehicles, and online transportation partners. Another thing is the Value proposition element such as prestige, by providing more added value to MyPertamina users compared to ordinary customers. The key partners element is added by private companies as partners and as full service users.

The recommended strategy after developing the MyPertamina e-commerce business model starts with the fulfillment of the MyPertamina ecosystem at all COCO (Companyowned) gas stations throughout Indonesia. In this case a product service improvement strategy is carried out by including a full service package for companies that want to use MyPertamina to support their business operations.

Offering business cooperation with similar vendors, namely Go-Pay or OVO, making fuel purchases at COCO gas stations, is to provide convenience and a feeling of prestige to MyPertamina users by providing a special path to purchasing fuel using MyPertamina at COCO gas stations.

\section{ACKNOWLEDGEMENTS}

Thank you to Mr. Andria Nusa as the Sales \& Marketing Manager of PT. Pertamina Retail which has given permission and facilities in conducting research at PT. Pertamina Retail.

\section{REFERENCES}

1. [APJII] Asosiasi Penyelenggara Jasa Internet Indonsia. 2017. Profil Pengguna Internet Indonesia. Jakarta: Asosiasi Penyelenggara Jasa Internet Indonesia (ID). https://apjii.or.id/content/read/39/27/profil-pengguna-internet-indonesia-2014.

2. [Pertamina Retail]. 2018. Corporate Profile PT. Pertamina Retail 2018. Jakarta (ID).

3. Drucker, Peter. F, 1996. Inovasi and Kewiraswastaan yang diterjemahkan oleh Rusjdi Naib. Jakarta (ID): Erlangga.

4. Giesen, E. Berman, S. Bell, R. Blitz, A. 2007. Path To Succecc Three Ways to innovate Your Business Model. IBM Global Business Service. VOL. 35 NO. 6 2007, pp. 27-33.

5. Kaplan RS, Norton DP. 2001. Transforming the Balanced Scorecard from Performance Measurement to Strategic Management: Part I. Accounting Horizons: March 2001, 15(1): 87-104.

6. Kotler \& Keller. (2008). Manajemen Pemasaran. Edisi Ketigabelas. Jilid 1. Jakarta (ID): Erlangga.

7. Seider WD, Seader, \& Lewin DR. 2000. Product and Process Design Principles: Synthesis, Analysis, and Evaluation. 2nd Edition.

8. Stefan S, Richard B. 2014. Analysis of business model. Journal of Competitiveness. 6(4): 1940.

9. Suki NMB, Ahmad I, and Thyagarajan V. 2002. Motivation and concern factors for internet shopping: A Malaysian perspective. The Electronic Journal for E-commerce Tools and Applications 1, 1-18. 